\title{
Erratum to: Headaches attributed to airplane travel: a Danish survey
}

\author{
Sebastian Bao Dinh Bui ${ }^{\dagger}$, Torben Petersen ${ }^{\dagger}$, Jeppe Nørgaard Poulsen and Parisa Gazerani
}

After publication of the original article [1] it was brought to our attention that there remained a number of grammatical errors in the article, which the author was concerned should be corrected. This has now been updated on the Springer Open website, although it won't be reflected on indexing sites such as PubMed. Please therefore refer to the Springer Open website for the corrections to this article.

Received: 19 April 2016 Accepted: 19 April 2016

Published online: 09 May 2016

\section{Reference}

1. Bui et al.: Headaches attributed to airplane travel: a Danish survey.

J Headache Pain 2016, 17:33.

*Correspondence: gazerani@hst.aau.dk

${ }^{\dagger}$ Equal contributors

SMI ${ }^{\oplus}$, Department of Health science and Technology, Faculty of Medicine, Aalborg University, Aalborg, Denmark
Submit your manuscript to a SpringerOpen ${ }^{\circ}$ journal and benefit from:

- Convenient online submission

Rigorous peer review

- Immediate publication on acceptance

- Open access: articles freely available online

- High visibility within the field

- Retaining the copyright to your article

Submit your next manuscript at springeropen.com 